\title{
Alginate Biosynthesis by Pseudomonas mendocina
}

\author{
By A. J. HACKING ${ }^{1 *}$, I. W. F. TAYLOR ${ }^{1}$, T. R. JARMAN ${ }^{1} \dagger$ AND \\ J. R. W. GOVAN ${ }^{2}$ \\ ${ }^{1}$ Tate \& Lyle Ltd, Group Research \& Development, P.O. Box 68, Reading, Berkshire RG6 2BX, U.K., \\ ${ }^{2}$ Department of Bacteriology, University of Edinburgh, Medical School, Teviot Place, \\ Edinburgh EH8 $9 A G$, U.K.
}

(Received 8 April 1983; revised 13 June 1983)

\begin{abstract}
Exopolysaccharide-synthesizing variants of Pseudomonas mendocina NCIB 10541 were isolated on media containing carbenicillin. The exopolysaccharide was identified as alginic acid with a mannuronic acid : guluronic acid ratio of $1: 2$. These strains lost the ability to produce alginate at a high frequency, but more stable mutants which produced increased amounts of polysaccharide could be isolated by subsequent mutagenesis. High concentrations of polysaccharide (approximately $20 \mathrm{~g}^{-1}$ ) were obtained in nitrogen-limited continuous culture with a minimal glucose medium. In common with other bacterial alginates, the polymer is acetylated and has similar rheological properties to alginate from brown algae. An alginate lyase activity was present in cultures at sufficient specific activities to result in a low molecular weight, low viscosity polymer with rheology similar to printing grade alginate. This degradation was overcome by incorporation of a proteolytic enzyme into the growth medium without adverse effects on bacterial or polysaccharide yields. As an organism for the study of alginate biosynthesis, $P$. mendocina possesses advantages over Azotobacter vinelandii or Pseudomonas aeruginosa in terms of yield, strain stability, and absence of known pathogenicity.
\end{abstract}

\section{INTRODUCTION}

Alginic acid is a $(1 \rightarrow 4)$-linked linear copolymer of $\beta$-D-mannuronic and $\beta$-L-guluronic acid synthesized by several species of marine algae (Booth, 1975) and produced as an exopolysaccharide by Azotobacter vinelandii (Gorin \& Spencer, 1966) and Pseudomonas aeruginosa (Evans \& Linker, 1973). Azotobacter vinelandii strains are usually mucoid when isolated and retain the ability to synthesize polysaccharide through repeated subculture (Jarman, 1979), although polysaccharide-negative mutants have been isolated and these remain viable under laboratory conditions (Sutherland, 1972). Alginate is also found in the cell walls of Azotobacter cysts (Sadoff, 1975).

Strains of $P$. aeruginosa do not in general produce alginate, but mucoid, alginate-producing variants are frequently isolated from the sputum of patients with cystic fibrosis (Doggett \& Harrison, 1969). The environmental factors proposed to account for their gradual emergence in such patients include prolonged antibiotic therapy (Doggett \& Harrison, 1969; Govan \& Fyfe, 1978; Kulczcki et al., 1978) and immunological selection through the protective effect of alginate on phagocytosis by alveolar macrophages (Schwarzmann \& Boring, 1971) and reduced pulmonary clearance (Govan et al., 1983). Alginate-producing mutants can be isolated in vitro by selection for resistance to phages (Martin, 1973; Govan, 1975) or antibiotics (Govan \& Fyfe, 1978). Mucoid variants isolated in vivo or in vitro are often unstable; non-mucoid revertants are frequently found at high frequencies because of a growth rate advantage over the parent strain (Govan, 1975). Stability can be improved by growth in the presence of surfactants or with

\footnotetext{
$\dagger$ Present address: Patscentre International, Melbourne, Royston, Herts SG8 6DP, U.K.
} 
agitation (Govan, 1975). Large-scale microbial alginate synthesis is not feasible with $P$. aeruginosa because it is an opportunistic pathogen. Only poor carbon conversion efficiencies have been obtained with $A$. vinelandii (Deavin et al., 1977; Jarman et al., 1978).

More recently, alginate-synthesizing strains of $P$. fluorescens, $P$. mendocina and $P$. putida have been isolated by selection on growth media containing carbenicillin (Govan et al., 1981). The present paper describes an investigation of alginate production by the saprophytic species $P$. mendocina (Palleroni et al., 1970) for which no pathogenic role has been reported (Gilardi, 1972) and which has been very rarely isolated from clinical material (Farmer, 1976).

\section{METHODS}

Growth and maintenance of organisms. Pseudomonas mendocina (NCIB 10541) was routinely subcultured on nutrient agar slopes. Pseudomonas aeruginosa PsB (Mian et al., 1978) was maintained on Pseudomonas isolation agar. Mucoid strains of $P$. mendocina, Muc 18, C7, U1 (NCIB 11687) and U3 (NCIB 11688) were maintained on agar $(1.5 \%, \mathrm{w} / \mathrm{v})$ containing a mineral salts medium (Jayasuria, 1955$)$ plus glucose $(2 \%$, w/v) for maximum polysaccharide synthesis. Viability on this medium is poor because of acid production and subculturing must be carried out at monthly intervals. For growth of shake flask cultures using the same minimal medium, sodium gluconate $(2 \%, \mathrm{w} / \mathrm{v})$ as carbon source did not result in acid production. The medium used in continuous culture contained $\left(\mathrm{g} \mathrm{l}^{-1}\right)$ : glucose, 90; $\left(\mathrm{NH}_{4}\right)_{2} \mathrm{HPO}_{4}, 1.25 ; \mathrm{K}_{2} \mathrm{HPO}_{4}, 1.25 ; \mathrm{Ca}(\mathrm{OH})_{2}, 0.05 ; \mathrm{Mg}(\mathrm{OH})_{2}, 0.07$; $\mathrm{MgSO}_{4} .7 \mathrm{H}_{2} \mathrm{O}, 0.14$; citric acid, 0.99 ; yeast extract, $0.2 ; \mathrm{MnSO}_{4} .4 \mathrm{H}_{2} \mathrm{O}, 1 \cdot 1 \times 10^{-3} ; \mathrm{FeSO}_{4} .7 \mathrm{H}_{2} \mathrm{O}, 3.6 \times 10^{-3}$; $\mathrm{ZnSO}_{4} .7 \mathrm{H}_{2} \mathrm{O}, 0.7 \times 10^{-3} ; \mathrm{CaSO}_{4} .5 \mathrm{H}_{2} \mathrm{O}, 0.25 \times 10^{-3} ; \mathrm{CoSO}_{4} .7 \mathrm{H}_{2} \mathrm{O}, 0.28 \times 10^{-3} ; \mathrm{H}_{3} \mathrm{BO}_{4}, 0.06 \times 10^{-3}$, $\mathrm{pH} 7 \cdot 0$. Glucose was autoclaved separately to avoid charring.

Carbenicillin resistance. An exponential phase culture of $P$. mendocina in nutrient broth was serially diluted and spread on to nutrient agar plates containing carbenicillin, initially in the range 0 to $1000 \mu \mathrm{g} \mathrm{ml}^{-1}$ in multiples of $100 \mu \mathrm{g} \mathrm{ml}^{-1}$. This gave an approximate indication of the MIC which was defined further by a second set of determinations over a narrower range in multiples of $20 \mu \mathrm{g} \mathrm{ml}^{-1}$.

Serial dilutions of an exponential phase culture of $P$. mendocina in nutrient broth were spread over nutrient agar plates containing 1.5 times the MIC of carbenicillin. The plates were examined after $36 \mathrm{~h}$ incubation at $30^{\circ} \mathrm{C}$. Resistant mucoid clones selected on the basis of their raised, glistening appearance were purified on minimal agar containing glucose $(2 \%, \mathrm{w} / \mathrm{v})$. The colony appearance of these isolates was recorded on deoxycholate/citrate agar, Pseudomonas isolation agar, minimal glucose agar $(0 \cdot 2,1 \cdot 0$ and $2 \cdot 0 \%, \mathrm{w} / \mathrm{v})$, minimal gluconate agar $(2 \cdot 0 \%, \mathrm{w} / \mathrm{v})$, nutrient agar and nutrient agar incorporating Tween $80(1.0 \%, \mathrm{w} / \mathrm{v})$ or Brij $35(1.0 \%, \mathrm{w} / \mathrm{v})$.

Mutagenesis. An exponential phase culture of $P$. mendocina in glucose $(10 \mathrm{~mm})$ mineral salts medium was harvested by centrifugation, washed in $0.5 \mathrm{M}$-Tris/maleate buffer, $\mathrm{pH} 6.0$ and resuspended in $9 \mathrm{ml}$ of this buffer to $0.5 \times 10^{9}$ cells ml ${ }^{-1} . N$-Methyl- $N^{\prime}$-nitro- $N$-nitrosoguanidine (Sigma) dissolved in the same buffer was added to a final concentration of $20 \mu \mathrm{g} \mathrm{ml}^{-1}$. After incubation for $30 \mathrm{~min}$ at $30^{\circ} \mathrm{C}$, the cells were harvested by centrifugation, washed in mineral salts medium and resuspended in $100 \mathrm{ml}$ salts medium plus glucose $(2 \%, \mathrm{w} / \mathrm{v})$. Measurements of viable cell concentration were made at all stages in this procedure. Cultures were grown for $24 \mathrm{~h}$ at $30^{\circ} \mathrm{C}$, the cells were collected by centrifugation, washed, resuspended in mineral salts medium, diluted and spread on to glucose $(2 \%, \mathrm{w} / \mathrm{v}) / \mathrm{mineral}$ salts agar plates to give 20 to 50 colonies per plate. Colony morphologies were examined after 4 to $6 \mathrm{~d}$ incubation at $30^{\circ} \mathrm{C}$.

Continuous culture. A laboratory fermentation vessel (L. H. Engineering Ltd, Stoke Poges, Buckinghamshire; type $1 / 1000$ ) modified for continuous culture (working volume $=2.51$ ) was used. The $\mathrm{pH}$ was maintained at 7.0 by the automatic addition of $2 \mathrm{M}-\mathrm{NaOH}$. The temperature was $30^{\circ} \mathrm{C}$. Foaming was controlled by the addition of a silicone antifoaming agent. Air was supplied at $11 \mathrm{~min}^{-1}$ and the culture was mixed at impeller speeds of 300 to 750 r.p.m. so as to maintain the dissolved oxygen at about $20 \%$ of saturation.

For continuous culture, medium addition was started when the batch culture reached the stationary phase. The dilution rate was adjusted by alteration of the rate of flow of medium. Following a change in conditions, a steady state was considered to exist when cell dry weight and oxygen uptake had remained constant for three residence times. Glucose concentrations in culture broths were determined by the glucose oxidase method using a Model 23A glucose analyser (Yellow Springs Instrument Co., Yellow Springs, Ohio, U.S.A.)

Cell dry weight. Bacterial cells and exopolysaccharide could only be separated in the presence of a chelating agent. Culture broth $(40 \mathrm{ml})$ was mixed with $5 \mathrm{M}-\mathrm{NaCl}(0.8 \mathrm{ml})$ and $0.5 \mathrm{M}-\mathrm{EDTA} \mathrm{pH} 7.0(0.8 \mathrm{ml})$ and after standing for $10 \mathrm{~min}$, was centrifuged at $24000 \mathrm{~g}$ for $40 \mathrm{~min}$. The supernatant was removed, the precipitate was resuspended in distilled water and centrifuged às before. The final precipitate was dried at $105^{\circ} \mathrm{C}$ to constant weight.

Polysaccharide determination. The first supernatant from the cell dry weight determination $(25 \mathrm{ml})$ was added to propan-2-ol ( $75 \mathrm{ml})$. After mixing and standing for $10 \mathrm{~min}$, the precipitate obtained was filtered on a pre-weighed Whatman GF/A filter disc which was dried in vacuo for $24 \mathrm{~h}$ and re-weighed. 
Analysis of exopolysaccharide. Infra-red spectral analysis of the sodium salt of the polysaccharide was carried out by the KBr disc method (Fillipov \& Kohn, 1974) using a Perkin-Elmer 457 infrared spectrometer.

The acetate content of the polymer was determined by the hydroxamate method of McComb \& McCready (1957).

Molecular weight profiles of polysaccharide were obtained by gel electrophoresis using $6 \%(w / v)$ polyacrylamide (Bucke, 1974).

Rheology. For a non-Newtonian fluid the apparent viscosity, $\eta$, is dependent upon the rate of shear and can be defined by: $\eta=K(\mathrm{~d} \gamma / \mathrm{d} t)^{x}$ (Van Wazer $e t$ al., 1963) where $K$ is the consistency index (apparent viscosity at a shear rate of $\left.1 \mathrm{~s}^{-1}\right), \mathrm{d} \gamma / \mathrm{d} t$ is the rate of shear and $n$ is the flow behaviour index. The higher the value of $K$, the more viscous the fluid. The flow behaviour index varies from 1 to 0 for pseudoplastic fluids; the lower its value the more pronounced are the non-Newtonian properties of the fluid.

Culture viscosity measurements were made using a model HAT cone-and-plate microviscometer (WellsBrookfield Engineering Laboratories Inc., Stoughton, Mass., U.S.A.) at $25^{\circ} \mathrm{C}$. For more viscous solutions a model HBT was used. The apparent viscosities were determined over a range of shear rates from 3.75 to $750 \mathrm{~s}^{-1}$ and $K$ was obtained by extrapolation of a $\log -\log$ plot of apparent viscosity against shear rate.

A more detailed rheological examination was made using a Rheomat-30 rotational viscometer with a cone-andplate system (Contraves A. G., Zürich, Switzerland). A $1 \%(\mathrm{w} / \mathrm{v})$ polysaccharide solution in $(a)$ distilled water and (b) $100 \mathrm{~mm}$-EDTA, pH 7.0, was prepared by continuous agitation for $1 \mathrm{~h}$ using a top-stirrer. Solutions were examined at 30 shear rates and values of $K$ and $n$ obtained from shear rate versus viscosity plots.

Preparation of cell-free extracts. Cells were harvested in the late-exponential phase of growth, washed in $0.1 \mathrm{M}$ phosphate buffer ( $\mathrm{pH} 7.0$ ) and suspended in four times their wet weight of the same buffer. In viscous cultures, 0.01 M-EDTA (sodium salt, $\mathrm{pH} 7.0$ ) was added to the wash buffer. The cells were sonically disrupted by $4 \times 20 \mathrm{~s}$ pulses $(20 \mathrm{kHz})$ in a tube chilled to $0{ }^{\circ} \mathrm{C}$ using an $\mathrm{NaCl}$ freezing mixture. The supernatant fluids were used for enzyme assays after centrifugation at $40000 \mathrm{~g}$ for $45 \mathrm{~min}$ at $0^{\circ} \mathrm{C}$.

Assay of alginate lyase activity. This assay measures unsaturated uronic acids released from the polysaccharide using the periodate/thiobarbituric acid method (Weissbach \& Hurwitz, 1959). Reaction mixtures $(2.0 \mathrm{ml})$ contained $0.1 \%(\mathrm{w} / \mathrm{v})$ Manugel in 0.1 M-potassium phosphate buffer ( $\mathrm{pH} 7.0)$. Assays were started by the addition of bacterial extract (1-2 mg protein). Control mixtures lacking enzyme or alginate were included. Samples $(0 \cdot 2 \mathrm{ml})$ were withdrawn from reaction mixtures after 10,20 and $30 \mathrm{~min}$ incubation at $30^{\circ} \mathrm{C}$. The reaction was stopped by the addition of $62.5 \mathrm{mM}-\mathrm{H}_{2} \mathrm{SO}_{4}(0.2 \mathrm{ml})$ and the sample was mixed with $0.02 \mathrm{M}$-periodic acid in $62.5 \mathrm{mM}-\mathrm{H}_{2} \mathrm{SO}_{4}$ $(0.2 \mathrm{ml})$. After $20 \mathrm{~min}$ incubation at room temperature, $2 \%(\mathrm{w} / \mathrm{v})$ sodium arsenite in $0.5 \mathrm{M}-\mathrm{HCl}(0.5 \mathrm{ml})$ was added. The mixture was shaken and, after standing for $2 \mathrm{~min}, 0.3 \%(\mathrm{w} / \mathrm{v})$ thiobarbituric acid $(2 \mathrm{ml})$ was added followed by heating for $10 \mathrm{~min}$ at $100^{\circ} \mathrm{C}$. After cooling, the absorbance at $549 \mathrm{~nm}$ was measured against a reagent blank. Enzyme activities are defined as nmol $\beta$-formyl pyruvic acid liberated (mg protein) ${ }^{-1} \min ^{-1} ; 10 \mathrm{nmol} \beta$-formyl pyruvic acid produces an $A_{549}$ of 0.29 under these conditions (Preiss \& Ashwell, 1962).

Chemicals. Commercial algal alginates (Manugel and Manutex) were obtained from Alginate Industries, Girvan, Ayrshire, U.K. Deoxycholate/citrate agar was from Oxoid, Pseudomonas isolation agar from BBL, carbenicillin from Beecham Pharmaceuticals and Neutrase from Novo Industri, Bagsvaerd, Denmark.

\section{RESULTS}

\section{Isolation of mucoid strains}

The MIC of carbenicillin for the wild-type strain of $P$. mendocina in the single cell dilution technique on nutrient agar was $80 \mu \mathrm{g} \mathrm{ml}^{-1}$. When suspensions of this strain were plated on to nutrient agar containing carbenicillin $\left(120 \mu \mathrm{g} \mathrm{ml}^{-1}\right)$, resistant colonies grew after 3 to $4 \mathrm{~d}$ incubation at $30^{\circ} \mathrm{C}$ as described by Govan et al. (1981). Mucoid colonies (e.g. Muc 18; C7; Table 1) were identified by their raised glistening appearance on glucose $(2 \%, w / v)$ minimal agar. Resistant colonies could not be obtained by plating directly on to glucose minimal agar containing carbenicillin even at concentrations as low as $50 \mu \mathrm{g} \mathrm{ml}^{-1}$. The capsular polysaccharide was provisionally identified as alginate by the formation of a white flocculent precipitate in $0.05 \mathrm{M}-\mathrm{H}_{2} \mathrm{SO}_{4}$ and by gelation in $0.01 \mathrm{M}-\mathrm{CaCl}_{2}$. Confirmation was later obtained by IR analysis and rheology.

Of the media tested, capsule production (as judged by colony morphology) in the mucoid strains was only apparent in mineral salts containing more than $1 \%(w / v)$ glucose, or on deoxycholate/citrate agar. The active components of deoxycholate/citrate medium appeared to be sodium deoxycholate and sodium thiosulphate, although neither alone was as effective in eliciting polysaccharide synthesis as the complete formulation. Incorporation of other 
Table 1. Alginate production by various strains of $P$. mendocina in shake flask cultures

All strains were grown in gluconate $(2 \%, w / v) /$ minimal salts medium. Propan-2-ol precipitation was carried out after $4 \mathrm{~d}$ incubation at $30^{\circ} \mathrm{C}$.

$\begin{array}{lc}\quad \text { Strain } & \begin{array}{c}\text { Alginate produced } \\ \text { (g propan-2-ol } \\ \text { precipitate } 1^{-1} \text { ) }\end{array} \\ \text { Wild-type (NCIB 10541) } & 0 \cdot 45 \\ \text { Muc18 (First stage carbenicillin-resistant isolate) } & 2 \cdot 0 \\ \text { C7 (First stage carbenicillin-resistant isolate) } & 1 \cdot 6 \\ \text { U1 (NCIB 11687) (Nitrosoguanidine mutagenesis of Muc18) } & 2 \cdot 8 \\ \text { U3 (NCIB 11688) (Nitrosoguanidine mutagenesis of Muc18) } & 3 \cdot 2\end{array}$

Table 2. Alginate synthesis by mutant U1 growing in continuous culture under nitrogen limitation at various dilution rates

Culture conditions and medium were as described in Methods. Glucose was supplied at $90 \mathrm{~g}^{-1}$ and the dissolved oxygen tension was maintained at approximately $20 \%$ of saturation. The yield of polysaccharide is defined as the ratio of the propan-2-ol precipitate to the glucose consumed by the culture.

$\begin{array}{ccccccc}\begin{array}{c}\text { Dilution } \\ \text { rate }\end{array} & \begin{array}{c}\text { Cell dry } \\ \text { weight } \\ \left(\mathrm{h}^{-1}\right)\end{array} & \begin{array}{c}\text { Propan-2-ol } \\ \text { precipitate } \\ \left(\mathrm{g}^{-1}\right)\end{array} & \begin{array}{c}\text { Cell: poly- } \\ \text { saccharide } \\ \text { ratio }\end{array} & \begin{array}{c}\text { Residual } \\ \text { glucose } \\ \left(\mathrm{g} \mathrm{I}^{-1}\right)\end{array} & \begin{array}{c}\text { Glucose } \\ \text { used by } \\ \text { culture } \\ \left(\mathrm{g} \mathrm{l}^{-1}\right)\end{array} & \begin{array}{c}\text { Yield } \\ \text { of poly- } \\ \text { saccharide }\end{array} \\ 0.03 & 2.7 & 17.5 & 6.5 & 33.5 & 56.5 & 0.31 \\ 0.04 & 2.5 & 18.0 & 7.5 & 32.0 & 58 & 0.31 \\ 0.06 & 2.5 & 23.5 & 9.2 & 25.5 & 64.5 & 0.36\end{array}$

surfactants, for example Tween 80 (polyoxyethylene sorbitan mono-oleate) or Brij 35 (polyoxyethylene-23-lauryl ether), into growth media was not effective. Colonies did not, however, appear mucoid on gluconate $(2 \%, \mathrm{w} / \mathrm{v})$ minimal agar, but alginate could be recovered from liquid cultures using this medium. An alginate-synthesizing strain of $P$. aeruginosa PsB appeared mucoid on all media tested.

When $P$. mendocina cultures grown on a non-inducing medium were transferred back to $2 \%$ glucose or deoxycholate/citrate agar the mucoid appearance was regained, but all strains tested were unstable. Constant segregation to small non-mucoid colonies occurred but instability was particularly apparent in liquid culture. In some cases less than $20 \%$ of the population retained polysaccharide synthesis after 60 mass doublings.

In an attempt to improve stability and polysaccharide yield, nitrosoguanidine-induced mutagenesis was carried out on one carbenicillin-resistant isolate (Muc 18). Distinct large spreading mucoid colonies could be observed amongst survivors of the mutation. A total of 35 such isolates was obtained by screening $10^{5}$ clones on glucose $(2 \%, \mathrm{w} / \mathrm{v}) /$ mineral salts agar without selective enrichment. Consistently greater propan-2-ol precipitates were obtained in shake flask cultures of these strains than in strain Muc18 or any of the first stage carbenicillinresistant isolates (Table 1). Shake flask culture using glucose as sole carbon source was difficult to reproduce because of high glucose dehydrogenase activity and release into the medium of gluconic acid which inhibited growth by lowering the $\mathrm{pH}$. Increasing the buffering capacity of the medium inhibited polysaccharide synthesis, so replacement of glucose by sodium gluconate was adopted as a standard procedure, but polysaccharide concentrations were never as high as using glucose in a pH-controlled fermenter. Approximately $50 \%$ of the large mucoid clones were unstable in shake flask culture as judged by the rapid appearance of small colonies, but the remainder (e.g. U1, U3; Table 1) were successfully subcultured for 70 mass doublings.

\section{Polysaccharide production in continuous culture}

High concentrations of polysaccharide were achieved by growth of one of the large colony isolates (strain U1) in continuous culture (Table 2). Optimal rates of polysaccharide synthesis 
Table 3. Stability of exopolysaccharide synthesis by mutant UI in continuous culture

Culture conditions were as described in Methods. The dilution rate was maintained at an average of $0.05 \mathrm{~h}^{-1}$ and dissolved oxygen tension at $20 \%$ of saturation.

$\begin{array}{ccc}\begin{array}{c}\text { Time after } \\ \text { inoculation }(\mathrm{h})\end{array} & \begin{array}{c}\text { Propan-2-ol } \\ \text { precipitate }\left(\mathrm{g}^{-1}\right)\end{array} & \begin{array}{c}\text { Percentage of } \\ \text { small colonies }\end{array} \\ 0 & 0 & 0 \\ 25 \cdot 6 & 15 \cdot 6 & 0 \\ 52 & 19 \cdot 0 & 5 \\ 122 & 15 \cdot 1 & 5 \\ 197 & 18 \cdot 5 & 17 \\ 298 & 20 \cdot 3 & 21 \\ 381 & 18 \cdot 4 & 35\end{array}$

Table 4. Effect of incorporation of various amounts of a proteolytic enzyme on culture viscosity

Cultures were maintained at a dilution rate of $0.05 \mathrm{~h}^{-1}$ and dissolved oxygen tension at approximately $20 \%$ of saturation. Other culture conditions and medium were as described in Methods.

$\begin{array}{cccc}\begin{array}{c}\text { Neutrase } \\ \text { (Anson } \\ \left.\text { units } ~^{-1}\right)\end{array} & \begin{array}{c}\text { Propan-2-ol } \\ \text { precipitate } \\ \left(\mathrm{g} \mathrm{l}^{-1}\right)\end{array} & \begin{array}{c}\text { Cell dry } \\ \text { weight } \\ \left(\mathrm{g} \mathrm{l}^{-1}\right)\end{array} & \begin{array}{c}\text { Culture consistency } \\ \text { index, } K \\ \left(\mathrm{mPa} \mathrm{s}^{n}\right)\end{array} \\ 0 & 18.5 & 3 \cdot 4 & 32 \\ 0.1 & 21 \cdot 0 & 3 \cdot 6 & 4700 \\ 0.25 & 19.6 & 3.0 & 5100\end{array}$

were obtained by maintaining the dissolved oxygen tension between 18 and $25 \%$ of saturation. Below this range polysaccharide concentration declined while above it concentrations were maintained but carbon conversion efficiencies from glucose fell, presumably because of increased substrate oxidation. Polysaccharide concentration increased with dilution rate to $0.06 \mathrm{~h}^{-1}$ but then fell sharply to less than $10 \mathrm{~g} \mathrm{l}^{-1}$ at $0.08 \mathrm{~h}^{-1}$, although cell dry weight remained constant. Nitrogen was established as the limiting nutrient in the medium used by adding $1 \mathrm{~g} \mathrm{NH}_{4} \mathrm{Cl}^{-1}$ to a culture at a steady state. Cell density rose from $2 \cdot 7 \mathrm{~g}^{-1}$ to $4 \cdot 1 \mathrm{~g} \mathrm{l}^{-1}$ after $12 \mathrm{~h}$ but then remained constant due to the establishment of a new limit.

When the mutant $U 1$ was maintained at a constant dilution rate of $0.5 \mathrm{~h}^{-1}$, strain instability as estimated by the appearance of small colonies was apparent (Table 3). This was not accompanied, however, by a corresponding drop in polysaccharide concentration, although when polysaccharide synthesis by these small colony types was measured in shake flask culture it was less than $50 \%$ of the starter culture of mutant U1.

\section{Degradation of polysaccharide}

All strains of $P$. mendocina used in this work were found to possess an alginate lyase activity which was present at specific activities of between 0.2 and $0.35 \mathrm{nmol} \mathrm{min}{ }^{-1}(\mathrm{mg} \text { protein })^{-1}$ in crude extracts independent of polysaccharide synthesis or growth substrate. The specific activities also remained unaltered throughout the course of continuous fermentations. Despite high concentrations of alginate, culture viscosities (as estimated by the culture consistency index) remained low unless a proteolytic enzyme was incorporated into the medium (Table 4). Addition of 'Neutrase' increased culture viscosities substantially. This enzyme preparation did not have an adverse effect on cell growth or polysaccharide synthesis.

Evidence was also obtained that the alginate lyase activity was normally intracellular and was only released by cell lysis. PAGE of polysaccharide indicated only high molecular weight material in exponential phase batch cultures. Lower molecular weight bands only appeared after 12 to $24 \mathrm{~h}$ in the stationary phase. Addition of sonicated cell extracts to high viscosity cultures resulted in a rapid drop in viscosity and faster migrating bands on electrophoresis. Similar results were obtained when polysaccharide breakdown was estimated by the concentration of free uronic acid groups using the thiobarbituric acid assay. 


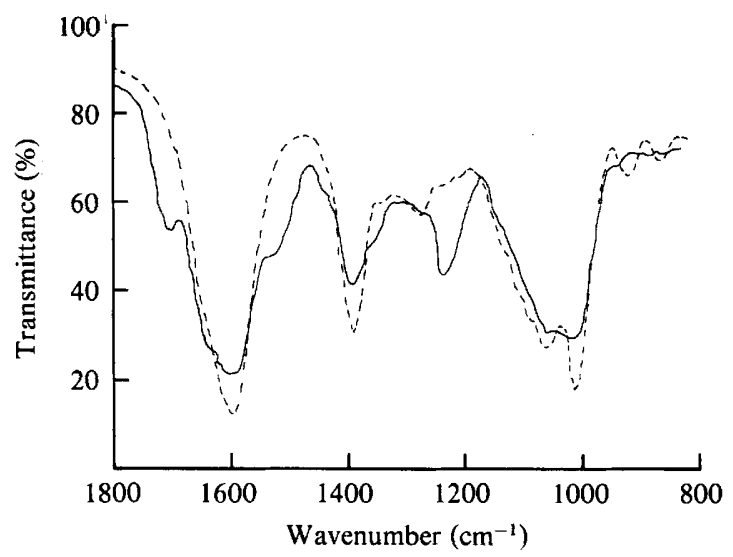

Fig. 1. Infra-red spectra of exopolysaccharide from $P$. mendocina grown in continuous culture under nitrogen limitation $(\longrightarrow)$ and commercial algal alginate $(---)$.

Table 5. Rheology of alginate samples

All samples were prepared as $1 \%(w / v)$ solutions and rheology measurements made as described in Methods.

\begin{tabular}{|c|c|c|c|}
\hline Sample & Solvent & $\begin{array}{l}\text { Consistency } \\
\text { index, } K \\
\left.(\mathrm{mPa} \mathrm{s})^{n}\right)\end{array}$ & $\begin{array}{c}\text { Flow } \\
\text { behaviou } \\
\text { index }(n)\end{array}$ \\
\hline \multirow{2}{*}{$\begin{array}{l}\text { Nitrogen-limited } \\
\text { culture without } \\
\text { protease }\end{array}$} & $\mathrm{H}_{2} \mathrm{O}$ & $9 \cdot 6$ & 0.86 \\
\hline & EDTA (100 mM) & 8.4 & 0.86 \\
\hline \multirow{2}{*}{$\begin{array}{l}\text { Nitrogen-limited } \\
\text { culture plus } \\
\text { protease }\end{array}$} & $\int \mathrm{H}_{2} \mathrm{O}$ & 8043 & 0.27 \\
\hline & EDTA $(100 \mathrm{~mm})$ & 557 & 0.43 \\
\hline \multirow{2}{*}{$\begin{array}{l}\text { Low molecular weight } \\
\text { algal alginate } \\
\text { (Manutex F) }\end{array}$} & $\int \mathrm{H}_{2} \mathrm{O}$ & $31 \cdot 4$ & 0.91 \\
\hline & EDTA (100 mM) & $12 \cdot 8$ & 0.98 \\
\hline
\end{tabular}

\section{Polysaccharide characterization}

The IR spectrum of exopolysaccharide from mutant U1 grown in continuous culture differs from algal alginate by having additional absorption peaks at $1250 \mathrm{~cm}^{-1}$ and $1720 \mathrm{~cm}^{-1}$ which correspond to $O$-acetyl ester (Fig. 1). It is similar to the spectra of alginate from $P$. aeruginosa and A. vinelandii (Evans \& Linker, 1973; Mian et al., 1978). The acetate content of the polymer was determined to be $12 \%(\mathrm{w} / \mathrm{v})$ and an approximate mannuronic: guluronic acid ratio of $1: 2$ was estimated from the absorbances at $1125 \mathrm{~cm}^{-1}$ and $1030 \mathrm{~cm}^{-1}$.

The rheological data (Table 5) indicate that without the addition of a proteolytic enzyme the $P$. mendocina polysaccharide has similar properties, including low pseudoplasticity, to the low molecular weight commercial alginate obtained from brown algae. With addition of protease a high viscosity product with similar properties to the high molecular weight algal product is obtained. Addition of EDTA lowers viscosity by chelation of divalent metal ions which form cross-links between chains.

\section{DISCUSSION}

Alginic acid can be synthesized by variants of $P$. mendocina selected in the presence of normally inhibitory concentrations of carbenicillin (Govan et al., 1981). A similar response has been observed in some strains of $P$. aeruginosa (Govan \& Fyfe, 1978). The mucoid variants of $P$. 
mendocina are unstable. Stability and yields of polysaccharide can be improved by selection of large mucoid clones after mutagenesis of carbenicillin-selected isolates. The reasons for this response to carbenicillin are unclear. Continued selection on carbenicillin attempted in this study resulted in the eventual dominance of non-mucoid resistant strains. Similarly, attempts to stabilize polysaccharide synthesis using surfactants were unsuccessful although this technique was used with $P$. aeruginosa (Govan, 1975). Polysaccharide synthesis by $P$. mendocina was also dependent upon growth medium, high concentrations of glucose giving the best results, whereas a mucoid strain of $\boldsymbol{P}$. aeruginosa synthesized exopolysaccharide on all growth media tested.

The polymer from $P$. mendocina is partially acetylated, in common with that from $A$. vinelandii (Larsen \& Haug, 1971) and P. aeruginosa (Evans \& Linker, 1973) but unlike that from the brown algae. This does not, however, seem to result in gross differences in rheology. The similarity in structure of a polysaccharide from such a range of organisms is interesting in view of the synthesis of very different exopolysaccharides by different wild-type strains of $P$. aeruginosa (Brown et al., 1969; Bartell et al., 1970).

The presence of an alginate lyase, albeit at very low intracellular activities, dramatically reduces the viscosity of culture broths. This suggests an endo-enzyme making possibly only a few breaks in a long chain. A similar effect has been observed in $A$. vinelandii cultures (Jarman, 1979). An inducible alginate lyase has been studied in Beneckea pelagia which is able to utilize alginate as a carbon source (Pitt \& Raisbeck, 1978), but $P$. mendocina in common with $\boldsymbol{A}$. vinelandii (Davidson, 1975) possesses low specific activities of this enzyme and is unable to grow on alginate. In $\boldsymbol{A}$. vinelandii, however, a role for the enzyme in breaking down alginate during encystment or cyst germination can be postulated. Lyase activity has been reported in $P$. putida and $P$. maltophila (Sutherland \& Keen, 1981) but not in $P$. aeruginosa. In this work intracellular activities similar to those in $P$. mendocina were detected in the alginate-synthesizing $P$. aeruginosa PsB although this organism does not degrade polymer in fermentations (Mian et al., 1978). The difference may lie in a lower rate of cell lysis or in a poor activity of the enzyme towards an acetylated polymer.

Alginate lyase activity can be overcome in continuous culture of $P$. mendocina by incorporation of a protease in the growth medium and concentrations of alginate of $20 \mathrm{~g}^{-1}$ were maintained for $400 \mathrm{~h}$ at a dilution rate of $0.05 \mathrm{~h}^{-1}$. The stability of this strain of $P$. mendocina was considerably better than that of $P$. aeruginosa PsB where $45 \%$ non-mucoid colonies were apparent after $112 \mathrm{~h}$ (Mian et al., 1978). Higher polysaccharide:cell ratios were also obtained in this work. Alginate synthesis by $A$. vinelandii suffers from poor carbon conversion efficiencies because the organism synthesizes poly- $\beta$-hydroxybutyrate (Jarman $e t$ al., 1978), and at higher oxygen tensions has very high respiration rates which result in low polysaccharide synthesis (Deavin et al., 1977). At present, therefore, P. mendocina appears to be the most suitable organism to study bacterial alginate synthesis on a larger scale.

We thank J. Brown, J. Rudland and B. Slowikowski for IR spectral analysis and rheology measurements. We also thank Dr K. Symes for PAGE and helpful discussions.

\section{REFERENCES}

Bartell, P. F., Orr, T. E. \& Chudio, B. (1970). Purification and chemical composition of the protective slime antigen of Pseudomonas aeruginosa. Infection and Immunity 2, 543-548.

BooTh, E. (1975). Seaweeds in Industry. In Chemical Oceanography, pp. 219-268. Edited by J. P. Riley \& G. Skikirrow. London: Academic Press.

Brown, M. R. W., Foster, J. H. S. \& Clamp, J. R. (1969). Composition of Pseudomonas aeruginosa slime. Biochemical Journal 112, 521-525.

BUCKE, C. (1974). Polyacrylamide gel electrophoresis of alginic acid. Journal of Chromatography 89, 99102.

DAvidson, I. W. (1975). Alginate lyases and their substrates. Ph.D. thesis, University of Edinburgh, U.K.

Deavin, L., Jarman, T. R., Lawson, C. J., RigheLATo, R. C. \& Slocombe, S. (1977). The production of alginic acid by Azotobacter vinelandii in batch and continuous culture. In Extracellular Microbial Polysaccharides pp. 14-26. Edited by P. A. Sandford \& A. Laskin. Washington: American Chemical Society. DogGett, R. C. \& Harrison, G. M. (1969). Significance of the pulmonary flora associated with chronic pulmonary disease in cystic fibrosis. In Proceedings of the 5th International Cystic Fibrosis Conference, pp. 175-178. Edited by D. Lawson, London: Cambridge Press. 
Evans, L. R. \& Linker, A. (1973). Production and characterisation of the slime polysaccharide of Pseudomonas aeruginosa. Journal of Bacteriology 116, 914-923.

FARMER, J. J., III. (1976). Pseudomonas in the hospital. Hospital Practice February 1976, pp. 63-70.

FILLIPOV, H. P. \& KoHN, R. (1974). Determination of composition of alginates by infra-red spectroscopic method. Chemical Zvesti 28, 817-819.

GILARDI, G. L. (1972). Infrequently encountered Pseudomonas species causing infection in humans. Annals of Internal Medicine 77, 211-215.

Gorin, P. A. J. \& Spencer, J. F. T. (1966). Exocellular alginic acid from Azotobacter vinelandii. Canadian Journal of Chemistry 44, 993-998.

Govan, J. R. W. (1975). Mucoid strains of Pseudomonas aeruginosa, the influence of culture medium on the stability of mucus production. Journal of Medical Microbiology 8, 513-522.

Govan, J. R. W. \& Fyfe, J. A. M. (1978). Mucoid Pseudomonas aeruginosa and cystic fibrosis: resistance of the mucoid form to carbenicillin, flucloxacillin and tobramycin and the isolation of mucoid variants in vitro. Journal of Antimicrobial Chemotherapy 4, 233-240.

Govan, J. R. W., Fyfe, J. A. M. \& Jarman, T. R. (1981). Isolation of alginate producing mutants of Pseudomonas fluorescens, Pseudomonas putida and Pseudomonas mendocina. Journal of General Microbiology 125, 217-220.

Govan, J. R. W., Fyfe, J. A. M. \& BaKer, N. R. (1983). Heterogeneity and reduced pulmonary clearance of mucoid Pseudomonas aeruginosa. Reviews of Infectious Diseases (in the Press).

JARMAN, T. R. (1979). Bacterial alginate synthesis. In Microbial Polysaccharides and Polysaccharases, pp. 35-50. Edited by R. C. W. Berkeley, G. W. Gooday \& D. C. Ellwood, London: Academic Press.

Jarman, T. R., Deavin, L., Slocombe, S. \& RigheLATO, R. C. (1978). An investigation of the effect of environmental conditions on the rate of exopolysaccharide synthesis in Azotobacter vinelandii. Journal of General Microbiology 107, 59-64.

JAYASURIA, G. C. N. (1955). The isolation and characteristics of an oxalate decomposing organism. Journal of General Microbiology 12, 419-428.

Kulczcki, L. L., Murphy, T. M. \& Bellanti, J. A. (1978). Pseudomonas colonization in cystic fibrosis. Journal of the American Medical Association 240, 3034.
LARSEN, B. \& HAUG, A. (1971). Biosynthesis of alginate. Composition and structure of alginate produced by Azotobacter vinelandii (Lipman). Carbohydrate Research 17, 287-296.

MARTIN, D. R. (1973). Mucoid variation in Pseudomonas aeruginosa induced by the action of phage. Journal of Medical Microbiology 6, 111-118.

McComb, E. A. \& MCCready, R. M. (1957). Determination of acetyl in pectin and in acetylated carbohydrate polymers. Analytical Chemistry 29, 819-821.

Mian, F., JARMAN, T. R. \& Righelato, R. C. (1978). Studies on the biosynthesis of exopolysaccharide by Pseudomonas aeruginosa. Journal of Bacteriology 134, 418-422.

Palleroni, N. J., Doudoroff, M., Stanier, R. Y. \& Solanes, R. E. (1970). Taxonomy of the aerobic pseudomonads: the properties of the Pseudomonas stutzeri group. Journal of General Microbiology 60, 215-231.

PITT, T. L. \& RaIsbeCK, L. C. (1978). Degradation of the mucoid polysaccharide of Pseudomonas aeruginosa by Beneckea pelagia. Journal of Applied Bacteriology 45, 297-300.

Preiss, J. \& Ashwell, C. (1962). Alginic acid metabolism in bacteria. 1. Enzymatic formation of unsaturated oligosaccharides and deoxy-L-erythro-5hexo-seulose uronic acid. Journal of Biological Chemistry 237, 309-316.

SADOFF, H. L. (1975). Encystment and germination in Azotobacter vinelandii. Bacteriological Reviews 39, 516-539.

Schwarzmann, S. \& Boring, J. R. (1971). Antiphagocytic effect of slime from a mucoid strain of Pseudomonas aeruginosa. Infection and Immunity 3, 762-767.

Sutherland, I. W. (1972). Bacterial exopolysaccharides. Advances in Microbial Physiology 8, 143213.

Sutherland, I. W. \& Keen, G. A. (1981). Alginases from Beneckea pelagia and Pseudomonas spp. Journal of Applied Biochemistry 3, 48-57.

VAN WAZER, J. R., LYONS, J. W., KIM, K. Y. \& COLWELL, R. E. (1963). Viscosity and Flow Measurement, p. 15. New York \& London: Interscience.

Weissbach, A. \& Hurwitz, J. (1959). The formation of 2-keto-3-deoxy-heptonic acid in extracts of Escherichia coli B. Journal of Biological Chemistry 234, 705-709. 